\title{
Organic Solid Waste Management and the Urban Poor in Dhaka City Mitali Parvin and Anwara Begum*
}

Bangladesh Institute of Development Studies (BIDS), Dhaka, Bangladesh

\begin{abstract}
Space within urban areas is differentially allocated among rich and the poor; existence for the poor becomes tenuous within conditions of environment degradation. Many migrants to the city are faced with uncertainties in their rural origins and opt for better opportunities in the city. However, in the city their activities are remunerated but meagre and without adequate provision for safety to health, in times of climate induced inundation. Urban management in this city is unsatisfactory but, theories conjecture an informality- organizing culture rather than lack of coordination and weak implementation. This paper contends that the problem will sustain, if addressed in a laissez faire manner. Management issues like garbage collection, freeing of effective space for remunerated economic activity, should be based on innovative approach which can minimize environment squalor. This paper delineates a management system for garbage disposal to free urban space to build a functionally viable city.
\end{abstract}

Keywords: Migration; Functional cities; Urban service; Garbage recycling; Waste management

\section{Introduction}

Bangladesh is the third most populated country in South-East Asia. The population of Bangladesh is around 15.25 crore according to the final results of Population and Housing Census, 2011. Bangladesh has a population density of approximately 1015 people per square kilometre. Bangladesh's population is now more than the collective population of four countries namely Thailand, Myanmar, Sri Lanka and Singapore. Majority of the people, especially in the urban areas, earn less than $\$ 1.25$ a day and live in degraded environment, which is inimical to their health and sustained livelihoods. Many of the poor inhabitants have migrated to the Dhaka Metropolis from the rural regions beset by structural inadequacies affecting lives and livelihoods (lack of employment throughout the year) and also displacement due to climate change, disasters and development related events.

The space within urban areas is differentially allocated for the rich and the poor; the challenge to remain viable, especially for the poor, becomes highly fragile because of lack of adequate urban services. There is lack of co-ordination between the urban authorities which lends itself to various types of exploitation. Where urban management in this metropolitan city is not satisfactory, various theories conjecture to project an informal culture rather than a lack coordination and failure of implementation. Recent literature has accepted the state of it's urban incoherence (informality) as an organizing urban logic [1]. However, this paper contends that the problem for the poor persists despite assumptions of informality being an organizing urban logic. Cities like Dhaka must resolve important management issues that can make urban living more congenial. The targeted, but critical urban management issues like garbage collection, thereby freeing of effective space for remunerated economic space, should be based on innovative approach which can minimize economic and environment degradation. This paper attempts to formulate a system of management for garbage disposal to make urban space more conducive for Dhaka city, towards attaining the status of a functionally viable city.

\section{Vulnerability of the urban poor}

The trend of migrants is towards areas which characterize plenty of livelihood opportunities and a chance to survive. Hence, the urban areas paradoxically exhibit, in miniature, the same inhospitable arrangements for migrants in both origin and destination areas. In reality the actors who have been pushed out of rural areas due to climate change then become part of the scenario that is rapidly contributing to climate change. Urban environment degradation has particular negative effects upon the overall health of the population but with specific negative consequences for the abject poor, who survive in the city, clinging to the assurance of a livelihood strategy.

In particular, the poor respond to the lack of livelihood support, constraints in rural common resources and opportunities and deteriorating economic socio-political scenario in the rural areas. Thus the expectations of dispersed, pushed and displaced populations, combined with changing livelihood situation of these migrating populations, need to be understood. More important, in fact, is that the reality is sour: the urban areas fail to fulfill expectations.

\section{Definition of poor}

In this study the poor are considered to be the people living under the poverty line (survive on less than 1.25 US\$ a day; The World Bank) and who are homeless or lead underprivileged lives in insecure and unsanitary conditions. They can be employed, unemployed, underemployed or irregularly employed who can hardly afford their basic needs and lives in slums, pavements, squatter and resettlement areas, sidewalks, dumpsites, road right-of-way, cemeteries, parks, unoccupied government or private lands or along danger zones like railroad tracks, riverbanks, or other places in urban areas. Nevertheless, these urban poor are a vital part of a society as they contribute to the urbanization, industrialization, different service sectors as well as economic growth.

The challenge being posed largely arise from the fact that large-scale internal migration generally to the metropolitan cities and particularly

*Corresponding author: Anwara Begum, Senior Research Fellow in the Bangladesh Institute of Development Studies (BIDS), Dhaka, Bangladesh. Tel: + 880-02-9143441-8; Fax: + 880-2-8141722; E-mail: anwarabids@gmail.com

Received December 27, 2017; Accepted January 02, 2018; Published January 09,2018

Citation: Parvin M, Begum A (2018) Organic Solid Waste Management and the Urban Poor in Dhaka City. Int J Waste Resour 8: 320. doi: 10.4172/22525211.1000320

Copyright: ( 2018 Parvin M, et al. This is an open-access article distributed unde the terms of the Creative Commons Attribution License, which permits unrestricted use, distribution, and reproduction in any medium, provided the original author and source are credited. 
to the capital city of Dhaka, is expected to continue at a pace, roughly calculated at around 4 to 5 percent per annum, although migration does not necessarily bestow the good life on all. Barring a few, there is modest experience of upward economic mobility. Migrants are continuing to move to a life of poverty in the city. The problem is compounded by the living and working conditions in which these people exist. The greatest threats to health and livelihoods arise from the heaped garbage, lack of sanitation facilities and environment pollution that surround them. There is evidence that some slums have mushroomed, like TT Para Bustee, on accumulated garbage in the Kamalapur area.

The notion of 'vulnerability to poverty' remains elusive [2,3]. There is no consensus about how to define and measure this subjective condition among a broad cross-section of people. Poor people identify their vulnerability as a condition that includes a serious threat and potential risks of exposure and helplessness against deprivation. Defense less ness is also manifested in social exclusion that may result in economic marginalization, exclusion and abject impoverishment. Thus, even though there is a lack of one to one correlation between vulnerability and poverty, there exists a close nexus between vulnerability and poverty as impoverishment tends to decrease alternative options and increase the risks of exploitation, which could become endemic, having been structurally conceived.

\section{Identifying the poor, vulnerable and marginalized}

The majority of people among the ultra poor (rural and urban), pavement dwellers, ethnic groups, disadvantaged people in depressed areas, chars, river erosion regions, suffering from physical and mental disabilities etc. are overwhelmingly and consistently suffering from these deprivations and it becomes imperative to assess and analyze the situation towards a strategy of alleviation.

The rapid growth of population, the mushrooming of poor settlements and unplanned urbanization have crucial implications for the efficiency and equity of urban services. The resultant infringements of critical human rights throw into focus the importance of housing as a social policy issue [4].

Female headed households are insecure due to lack of law and order. They are also dependent on common resources and Khas land which are dwindling rapidly. In the urban scenario, poor men, women and children resort to occupying the streets of the cities and do not own the roof (neither concrete nor made of temporary materials like tin scraps, gunny bags, polythene, cardboard etc.) over their heads. The poor are heterogenous in their abilities, needs, capacities and expectations [5]. Many of the street dwellers are negatively selected by age, sex, education. They do not have transferable skills. There is now an imperative need to target the poor in conformity with the Sixth and Seventh Five Year Plans and the Sustainable Development Goals of Bangladesh.

Due to environmental problems in urban areas of Bangladesh, waste management has become a matter of major concern. Rapid population growth along with increase in per capita income as well as abandoned urbanization is severely degrading the urban environment. The present waste management situation in Bangladesh needs modernization and innovative approach for its proper management. Two case studies are given below to illustrate the problems of the poor, due to garbage in the city:

\section{Case Study 1}

\section{Garbage disposal and socio-economic condition}

On the 22 of September 2016, 3 pm., we went to the local area slum, next to BIDS. Nasim is a 40 year old, illiterate man, living in this slum next to BIDS, since the last 10 to 12 years. He has 4 children of which the second child is a daughter studying in class 8 . The garbage dump is close by and they try to keep the immediate vicinity clean. Their problem of skin irritation and cough does not heal. They suffer from itching which is persistent.

About 40 families stay in this slum next to the main gate of BIDS. Garage shops have sprung up in the locality.

Beauty, aged 25 years, has come from Comilla. She has two children, a son and a daughter; one is aged about 3 years and the other is 1 year Her father migrated when she was not born so she can recall this slum as her birth place. They had lost their agricultural land due to river erosion.

She pays a monthly amount of Tk.50 for garbage disposal (this is picked up by DCC in the afternoon). She owns a tin shed which is about $12 \mathrm{ft} \times 12 \mathrm{ft}$ or 144 sq.ft. They suffer from problems emanating from water, environment pollution, electricity and garbage disposal. They buy fuel at tk.10 per kg. of wood (for fuel) and they use $3 \mathrm{kgs}$ of fuel every day incurring a cost of 30 takas for fuel. They use mud stove and the fuel is basically wood. They produce $1 \mathrm{~kg}$ of garbage every day. Flies abound in their tin shed, probably from the garbage dump in the vicinity.

Her son is allergic to mosquito bites and most of the time the children are ill. Flies are abundant due to the nearby garbage. They suffer from smell and excess of stagnant water. They do not know about compost creation. Their eyes become red when they go out, under the sun. They also experience aches in their eyes.

\section{Case Study 2}

TT Para Slum in Mugdapara, Gopibag, had grown up on top of a city-garbage dump. The residents of this slum did not pay any rent. The environmental conditions were extremely bad due to the rotting waste upon which the houses had been constructed [6]. This was inimical for the health of the residents, who complained about eye and skin ailments.

About three hundred and sixty households are in this slum and extreme poverty makes it the only option for them. Many utilize the dried garbage and cow dung for fuel and use public toilets and water sources. A similar situation exists in Mohammadpur, in a slum near Bansbari where the houses are constructed over the stagnant sewerage of the drains north-east of the Rayerbazar Matyr's Tomb. Most of the children are suffering from night blindness as the fumes from the black water under the homes, rise upwards through the bamboo floor and makes their eyes sting [7].

\section{Objectives of the Study}

The objectives of the paper are as follows:

- Urbanization in Bangladesh.

- Solid Waste Management Situation.

- Problems of Solid Waste Management in Urban Areas of Bangladesh.

- As a solution: 3R concept.

- $\quad$ Organic waste Composting: Approach of Tyre Tube Bio gas Plant \& Approach Followed by Waste Concern. 
- How Solid Waste is Converted into Resource Through PublicPrivate-Community Partnerships (PPCP)?

\section{Urbanization in Bangladesh}

\section{Urban population in Bangladesh}

Bangladesh's rapid urbanization is a reality replete with both threat and hope. The threat is obvious: due to high rate of population growth and rapid urbanization (Table 1). Overcrowding, pollution, poverty, impossible demands for energy and water all result in an overwhelming sense, the unplanned, megacity. The potential efficiencies of urban living, the access to health care and jobs, along with reducing urban birth rates have all convinced some environmental theorists the resettlement to the cities. Urbanization is the driving force leading to pollution.

Urbanization in Bangladesh is facing a crisis. Without corresponding expansion of the infrastructure the capital city-centric development strategy has led to an explosion of Dhaka city's size. Basic urban utilities are now in acute shortage as a result.

\section{Demographic profile of Dhaka mega city}

The population of Dhaka is now nearly 15 million (Figure 1) within its city area of $360 \mathrm{sq} . \mathrm{km}$. The population of Dhaka city has increased rapidly, with a growth rate of $3.72 \%$ per year. In Dhaka City Corporation (DCC) area 60\% low income houses, 37\% middle income and the rest $3 \%$ constitutes high-income houses [8]. The new part of Dhaka is less densely populated than the old part of Dhaka. In Dhaka Metropolitan Area there are over 1,000 small and large industries including 149 tanneries, about 500 clinics and hospitals.

In terms of population, in the year 2000 Dhaka was the 11th biggest city and will be the 4 th largest city in world in 2015. Total Population of Dhaka Mega city was 12.3 million (2002), the DCC Population was 6.8 million (2006) and now 15 million (2012). At present Dhaka is a land hungry city with 23,029 people (2011) living per square kilometer.

\section{Issues regarding urbanization}

\begin{tabular}{|c|c|c|}
\hline \multirow{2}{*}{ Year } & \multicolumn{2}{|c|}{ Urban Population Density/Sq.Km. } \\
\cline { 2 - 3 } & Dhaka & Dhaka City \\
\cline { 2 - 3 } & Mega City & Corporation Area \\
\hline 1991 & 4795 & 15333 \\
\hline 2004 & 8573 & 18055 \\
\hline 2011 & $\mathbf{1 9 , 4 4 7}$ & $\mathbf{2 3 , 0 2 9}$ \\
\hline
\end{tabular}

Table 1: Population growth and rapid urbanization.

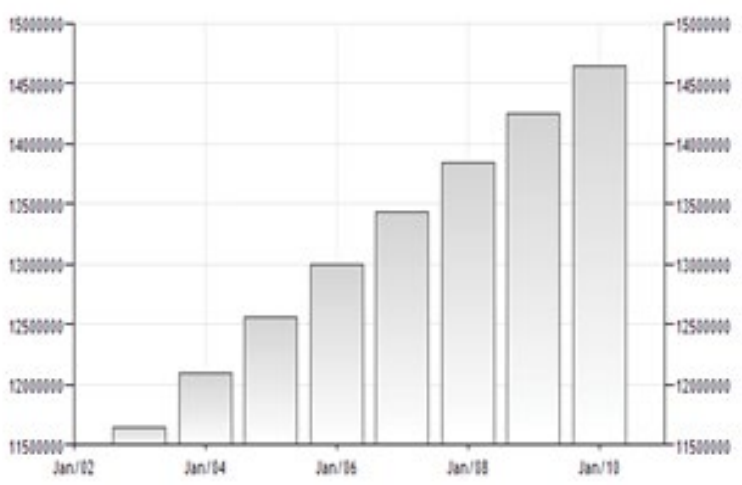

Figure 1: Population of Dhaka city.
The unparalleled urbanization of Dhaka has led to severe pressure on the service delivery sector. Urban poor are the worst sufferers as most poor households have to rely on unusual arrangements that imply lower quality and higher costs to get access to services resulting adverse effect on their value of life. The major issues regarding urbanization are as follows:

High population growth and high population density: The population of Bangladesh is around 15.25 crore with an annual growth rate of 1.37 percent, according to the final results of Population and Housing Census, 2011 [9].

Unemployment: Unemployment is an immense alarm in Bangladesh. Every year hundreds of thousands student are coming out from college and university. Though it is one of the major responsibilities of the Government to afford job to those young generation but the Government is failed to assemble the job demand among the large population. Only a tiny fraction of total jobless is managed by different government offices and private organization but a majority stay jobless.

Energy crisis: Presently the government of Bangladesh is not able to provide any new gas connections to households. Even previously existing connections in Dhaka are shut down regularly due to gas shortages. Some people are able to use gas only in the night.

Environmental pollution: Pollution has become a severe threat. Environmental pollution is as old as the evolution itself. In the last few decades it has become a major alarm. Pollution is the by-product of the progress of development and in fact a price for the progress. It is more prone in case of Bangladesh. The air quality remains dangerously poor. The water resource becomes a major health hazard due to arsenic contamination, inadequate solid waste and industrial effluent management of Bangladesh. Necessary steps are to be taken to care for the environment for our own existence.

Waste management: On a geographical area with 160 million people and a dysfunctional municipal waste handling system is a major problem. Low-lying areas, drains and canals are in Dhaka clogged with waste. Waste generation is rapidly increasing as the per capita income is increasing. Waste pollution is a serious problem and it has a significant health treats not only in Bangladesh but also in the Dhaka city. Household, medical, and electronic wastes are increasing in volume and worsening in composition. It has a negative impact on the city's environment as causing pollution.

\section{Solid Waste Management Situation and Problems}

\section{Solid waste management situation of Dhaka city}

Around 3000 to 4000 tons of waste is generated by households every day in Dhaka City inhabited by an estimated 15 million people. The only formal organization "The Dhaka City Corporation (DCC)" is responsible for waste management and collects less than half of the waste. Out of the waste collected, in the landfills $40-50$ percent is disposed. The rest stay behind unattended on roadsides, in open drains, locally dumped in low-lying. Since Methane gas is released from municipality waste this has a harmful impact on the city's environment as well as on the global climate which is twenty-one times more damaging than carbon dioxide causing air pollution. Dhaka city has only 1 official landfill site and be short of appropriate vacant land for disposal of waste.

\section{The waste management system for households in Dhaka}

Dhaka City Corporation (DCC) holds the official responsibility for 
solid waste collection, transportation and final disposal of generated within its service area.

\section{Waste generation scenario of Dhaka city}

According to a World Bank report, the solid waste generation of Dhaka in 1998 was 3,944 tons/day [10]. Another report stated that no less than 3,700 tons per day waste generated of DCC area [11]. Some other reports state that waste generation is about 4,000 to 5,000 tons/ day of DCC [9]. According to JICA team of "Clean Dhaka Master Plan" the existing solid waste generation (dry season) within Dhaka City Corporation area was 3,340 tons/day in 2004, will increase to 4,600-5,100 tons/day in 2015 [12]. The waste generation would be a little higher during the summer when fruits are available abundantly, which may result in 3,500 tons of average waste generation per day [12]. Nearly $20 \%$ is used for recovery and recycling and about $37 \%$ remains scattered laying around on roadsides, open spaces or in drains the total waste produced. JICA's study was limited to $131 \mathrm{~km}^{2}$ area of the city whereas DCC's solid waste management service area is $276 \mathrm{~km}^{2}$ [12].

\section{Waste generation scenario of Bangladesh}

In Bangladesh more than 15,000 tons of waste is produced each day. Total waste in urban areas of Bangladesh was about 13332.89 tons per day in 2005 (Table 2). It will be 47,000 tons of waste in 2025 and only a portion of it will be systematically handled. Per capita waste generation was $0.56 \mathrm{~kg} /$ day of Dhaka city and total waste generation of DCC was 38 tons/day in 2005. On the other hand, $70-80 \%$ of the solid municipal waste is organic. The organic waste poses a major potential for manufacture of fertilizer and biogas etc. To some extent, lack of municipal support for solving the problems and challenges are necessitate of source separation, inadequate collection, shortage of land for disposal/handling and. Estimated average per capita urban waste generation rate is as $0.41 \mathrm{~kg} / \mathrm{capita} /$ day.

\section{Waste generation of Dhaka city and Bangladesh}

Solid waste generation scenario of Dhaka city

- $\quad$ Per Capita Waste Generation: $0.56 \mathrm{~kg} / \mathrm{cap} /$ day

- Total Waste Generation DCC Area: 3800 tons/day

- $70 \%-80 \%$ of the solid waste is organic

Urban waste generation (tons/day) in Bangladesh
- 1991: 6493 tons/day

- 2005: 13,300 tons/day

- 2025: 47,064 tons/day (estimated)

\section{The waste collection challenge in Dhaka}

Municipal Corporation is unable to impose rules on the public. On the institutional side, rules and regulations are not clear. The role and responsibilities of waste generators are not clearly defined i.e., the present law does not provide penalties for illegal disposal of waste or littering. Lacks scientific approaches for problem solving and DCC has shortages of skilled human resources and finances. The accumulating waste is dumped by the residents in the city's streets, open storm water and wastewater drains or open water bodies where and whenever the collection service is inexistent or dysfunctional. In particular, slum or periphery areas are affected by such a situation. During the annual monsoon rains wastewater and storm water drains which are clogged by solid waste overflow, creating an acute sanitary and hygienic threat in low-lying slum areas particularly (Figure 2).

\section{Households garbage composition in Dhaka}

A households survey was conducted by the project "Challenge for a clean city (Dhaka)"by Tanzina Azad on household waste management on their behaviour towards waste sorting, dumping and recycling in 5 locations of Dhaka city at Dhanmondi, Paribagh, New Eskaton, Mohakhali and Purana Paltan. According to the result of the households survey $70 \%$ households buy their daily commodities from local shop, $25 \%$ buy from large supermarkets and rest of 5\% from other sources. None of them produce their commodities in home.

The average weekly households discarded garbage is around $7 \mathrm{~kg}$. Among the garbage decomposable wastes 78\%, plastic waste10\%, 5\% cartoon empty boxes, $3 \%$ glasses, $3 \%$ empty tins, rest $1 \%$ is other waste (Figure 3).

\section{Composition of urban solid waste}

In Dhaka city, Waste concern conducted a research on the components in the waste materials. It found that compost organic waste was $70-80 \%$ of the total generated waste, $15 \%$ recyclable and the rest was neither compost nor recyclable (Figure 4 ). The $15 \%$ recyclable waste was already being collected by the waste pickers and reused as

\begin{tabular}{|c|c|c|c|c|c|c|c|}
\hline \multirow{3}{*}{ City/Town } & \multirow[t]{3}{*}{$\begin{array}{c}\text { *WGR } \\
\text { (kg/cap/day) }\end{array}$} & \multirow[t]{3}{*}{$\begin{array}{c}\text { No. of } \\
\text { City/Town }\end{array}$} & \multirow{3}{*}{$\begin{array}{c}\text { Total } \\
\text { Population } \\
(2005)\end{array}$} & \multirow[t]{3}{*}{$\begin{array}{l}\text { Population** } \\
\text { (2005) }\end{array}$} & \multicolumn{2}{|c|}{ TWG $^{\star * *}$ (Ton/day) } & \multirow{3}{*}{$\begin{array}{l}\text { Average } \\
\text { TWG } \\
\text { (Ton/day) }\end{array}$} \\
\hline & & & & & & & \\
\hline & & & & & Dry season & $\begin{array}{c}\text { Wet } \\
\text { season }\end{array}$ & \\
\hline Dhaka & 0.56 & 1 & $61,16,731$ & $67,28,404$ & $3,767.91$ & $5,501.14$ & $4,634.52$ \\
\hline Chittagong & 0.48 & 1 & $23,83,725$ & $26,22,098$ & $1,258.61$ & $1,837.57$ & $1,548.09$ \\
\hline Rajshahi & 0.3 & 1 & $4,25,798$ & $4,68,378$ & 140.51 & 205.15 & 172.83 \\
\hline Khulna & 0.27 & 1 & $8,79,422$ & $9,67,365$ & 261.19 & 381.34 & 321.26 \\
\hline Barisal & 0.25 & 1 & $3,97,281$ & $4,37,009$ & 109.25 & 159.51 & 134.38 \\
\hline Sylhet & 0.3 & 1 & $3,51,724$ & $3,86,896$ & 116.07 & 169.46 & 142.76 \\
\hline Pourashavas & 0.25 & 298 & $13,831,187$ & $15,214,306$ & $3,803.58$ & $5,553.22$ & $4,678.40$ \\
\hline Other Urban Centers & 0.15 & 218 & $83,79,647$ & $92,17,612$ & $1,382.64$ & $2,018.66$ & $1,700.65$ \\
\hline Total & - & 522 & $32,765,516$ & $36,042,067$ & $10,839.75$ & $15,826.04$ & $13,332.89$ \\
\hline
\end{tabular}

Note: *WGR= Waste Generation Rate, ${ }^{* *}$ Including $10 \%$ increase for floating population, ${ }^{* * *}$ TWG $=$ Total Waste Generation, which increases $46 \%$ in wet season from dry season Source: 1 JICA (2004), 2 Chittagong City Corporation, 3 Field Survey, 4 Sinha (2000), 5 Field Survey, 6 Sylhet City Corporation, 7, 8 Field Survey.

Source: www.wasteconcern.org 


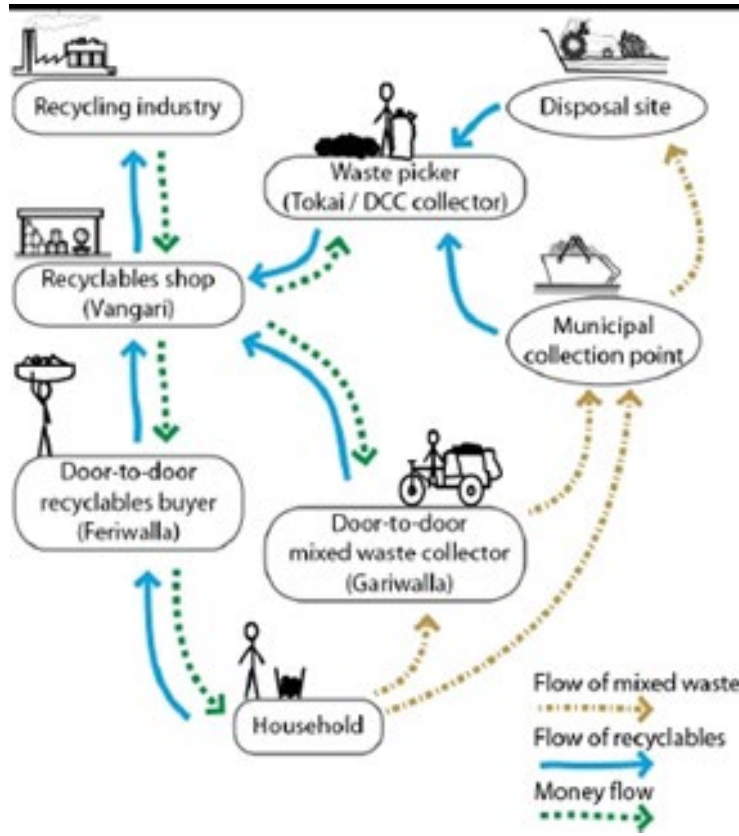

Figure 2: Schematic overview of the waste management system for households in Dhaka. Source: Anne Matter

they found. Major portion of the waste is organic. The $70-80 \%$ organic waste could be turned into resource by manufacturing it as compost for agricultural use (Figure 4). "Waste is a resource" 'Waste Concern' came forward with that label.

\section{Problems/negative impacts of organic waste}

Based on end-of-pipe solution, solid waste management is only focused on collection, transportation and final disposal. In most of the cities and towns open dumping practiced which is the cheapest and easiest solution. The negative impacts such Methane gas, bad odor and greenhouse gas, Vermin's spreading more than 40 diseases and when as leachate polluting surface and ground water. The most adverse impact of solid waste is occurrence and prevalence of various diseases in urban areas. In Dhaka, the worst impacts are dhong fever, malaria, respiratory problems, skin and eye diseases. Moreover, such adverse health impacts also lead due to contamination of ground water and air. On the other hand, the drainage system blocks by solid waste and create flooding in the streets leading towards mosquitoes, bad odor, and inconvenience. Dhaka is prone to flooding with its geographical and climatic conditions; hence, solid waste in the streets and drains multiplies the health impacts and miseries. Contaminated ground water and malaria are the major causes for child mortality.

\section{Soil condition of Bangladesh}

Bangladesh has $83 \%$ of cultivable land in which less than $3.5 \%$ organic matter or more than $3.5 \%$ is considered to be good soil (Figure $5)$.

\section{Waste Management and 3R Concept}

An integrated management plan is necessary for management waste based on the $3 \mathrm{R}$ principal which is the proposed solution (Figure 6). Here, most preferred to waste reduction and least preferred landfilling. The integrated plan has three major components of:

1. Waste collection: A door-to-door waste collection process

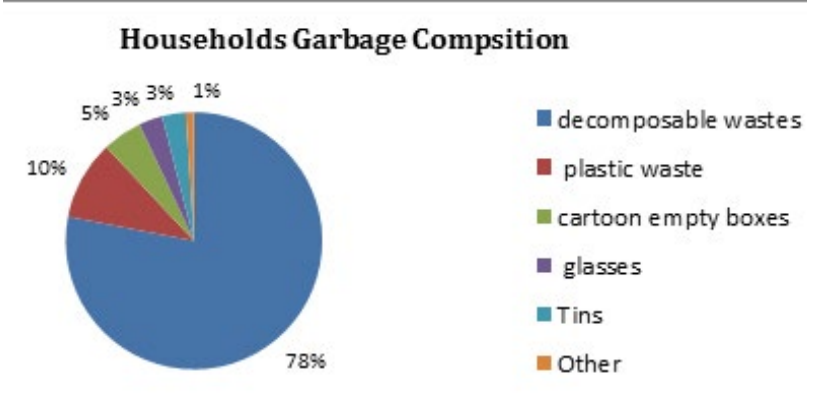

Figure 3: Households garbage composition.

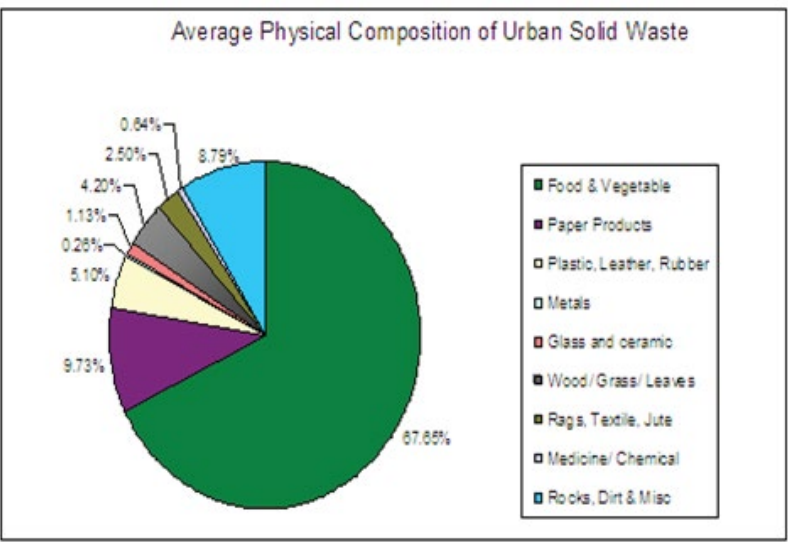

Figure 4: Physical composition of urban waste.

using rickshaw vans implemented by micro-enterprises in the city.

2. Waste prevention: Reduce, Reuse, Recycle a National 3R Law was developed and went into effect in 2009. It included a landmark policy banning the production, distribution, marketing and use of polythene bags which first went into law in 2002.Minimizing waste in as many stages is possible.

3. Waste disposal: Theplans ofthe Dhaka City Corporation to construct an expansion to the Matauail landfill and Amin Bazar landfill site. Leachate collection and treatment facilities will have of the controlled landfills. The closure of the Berri Band landfill will also result in by the project.

\section{Recycling industries in Dhaka city}

Due to rising prices of imported materials such as plastic resin, glass or paper, waste separation and recycling sector has developed itself asan informal in reaction to a demand for recyclable materials by the industrial sector. The informal sector is involved about 120,000 urban poor from in the recycling trade chain of Dhaka city. The total generated waste in Dhaka about 15\% of mainly inorganics (paper, bones, polythene, aluminum, plastic, glass) which amounts 475 tons/ day are recycled daily (Table 3 ).

\section{Composting Technique}

Composting is a method of capture value of organic portion of the solid waste. However, of the solid municipal waste about $70-80 \%$ is organic and poses a major potential for production of fertilizer and 


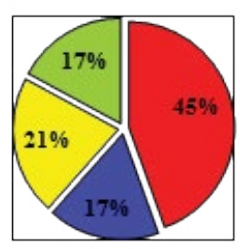

\section{$\square$ Very low $(<1.0 \%)$ \\ $\square$ Low $(1.1 \%-1.7 \%)$ \\ $\square$ Medium (1.71-3.50 \\ $\square$ High ( $3.5 \%$}

Figure 5: Pie diagram showing depletion of organic matter from the soil of Bangladesh.

\section{Hierarchy of Waste Pyramid}

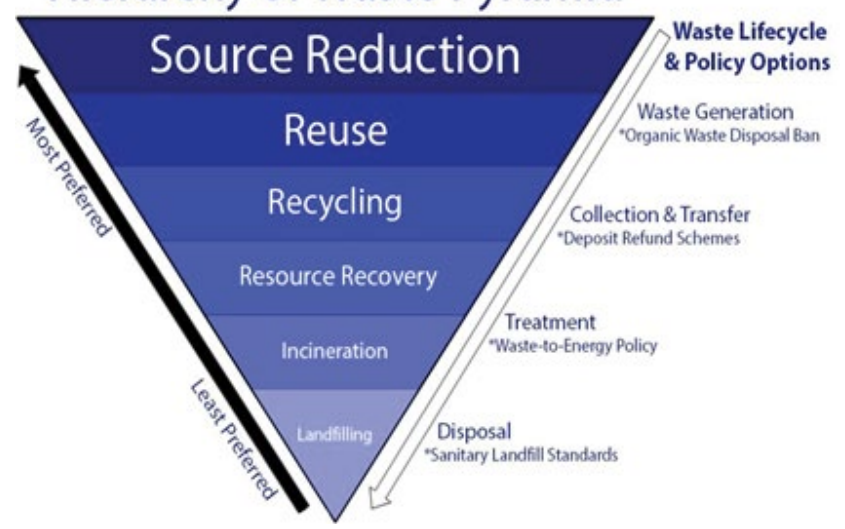

Figure 6: Hierarchy of waste pyramid.

biogas.

\section{Proposed solution at household's level: Zobayer's tyre tube biogas plant}

Recently, Mr. Zobayer has invented a Tyre Tube Roof top biogas plant in Bangladesh (Figure 7). According to his name it is called Zobayer Tyre Tube Biogas plant. It is the first Tyre Tube Roof top biogas plant in Bangladesh. In Bangladesh, most biogas plants elsewhere are designed to make use of poultry droppings and animal manure as their main feedstock. Comparably that type of biogas plant is big in size and only used in rural areas. More efficient waste management is needed in cities. In Bangladesh, the worsening gas situation resulted in the idea to try out small biogas plants for urban use. Currently, any new gas connection to households is not able to afford by the government of Bangladesh. In Dhaka due to gas shortages still already existing connections are shut down regularly. In the night only some people are capable to use gas. For that reason in Bangladesh there is a good opportunity and demand for biogas plants. Rooftop tube-type biogas plant can help to produce biogas and organic fertilizer which could be used in rooftop gardening and improve the waste management in a multistoried building. With low space requirements the principle is to capture gas from household (kitchen) waste in small and affordable anaerobic biogas plants. For methane production, the developed tubetype rooftop biogas plant by Zobayer is best run with kitchen and food waste. Kitchen waste has a higher energy density compared to manure as feedstock and digestion takes place rapidly.

Handling of the plant and waste: The kitchen waste and food waste (wet organic material) is collected in bins and containers brought to the rooftop. The waste is then mixed with water twice daily $1 \mathrm{~kg}$ of kitchen waste with 2 liters of water and into the inlet of biogas digester is directly charged, where the material breaks down by bacteria and

\begin{tabular}{|c|c|c|c|c|}
\hline City/Town & $\begin{array}{c}\text { TWG* } \\
\text { (Tone/ } \\
\text { day) }\end{array}$ & $\begin{array}{c}\text { No. } \\
\text { ofCity/ } \\
\text { Town }\end{array}$ & WasteRecycling** & $\begin{array}{c}\text { Savings } \\
\text { Wroughrecycling per } \\
\text { year (Tk. million) }\end{array}$ \\
\hline Dhaka & $4,634.52$ & 1 & 15.00 & 170.00 \\
\hline Chittagong & $1,548.09$ & 1 & 12.45 & 28.96 \\
\hline Rajshahi & 172.83 & 1 & 6.7 & 1.00 \\
\hline Khulna & 321.26 & 1 & 6.00 & 6.94 \\
\hline Barisal & 134.38 & 1 & 5.42 & 5.14 \\
\hline Sylhet & 142.76 & 1 & 4.23 & 3.44 \\
\hline Pourashava & $4,678.40$ & 298 & 3.89 & $8,862.52$ \\
\hline Other Urban & $1,700.65$ & 218 & 4.00 & $1,627.50$ \\
\hline Centre & $13,332.89$ & 522 & - & $\mathbf{1 0 , 7 0 5 . 5}$ \\
\hline Total & 13.29 & $\mathbf{( 1 5 . 2 9}$ million US \$) \\
\hline
\end{tabular}

Note: Source: www.wasteconcern.orgNote: 1 US \$=70Tk

Table 3: Showing total savings through recycling in Bangladesh about 15.29 million US \$ in 2005.

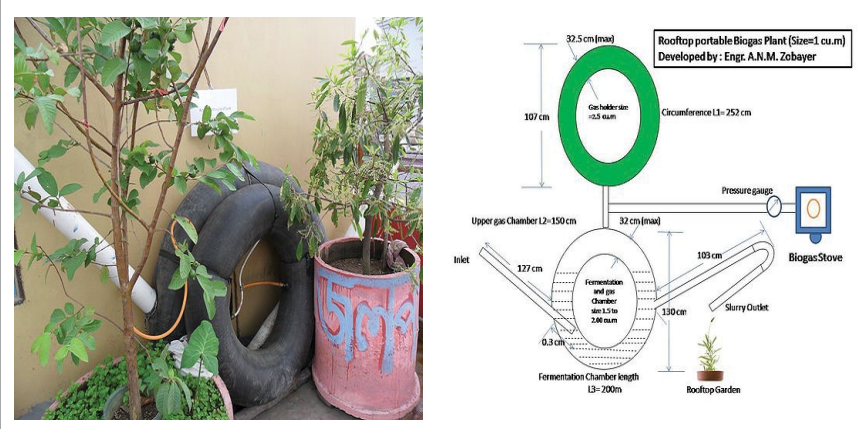

Figure 7: Zobayer's tyre tube biogas plant.

releases biogas [13]. The biogas digester is connects to the gas stove for cooking by a rubber pipe. The biogas digester lets out the very watery slurry from the outlet which can be used as organic fertilizer. The pressure of the biogas that is available for cooking purposes is used to monitor by a pressure gage. The plant is pressurized through weight on the gas holder instead of a hydraulic chamber is not applied. The capacity to hold $1.0 \mathrm{~m}^{3}$ gas by the biogas plant and enough biogas is able to provide to cook for 1.5 hours (in total) per day. As byproduct, produces best quality organic fertilizer which can be used as roof top gardening [14].

\section{Specialty of the roof top biogas plant:}

- The roof top biogas plant is made out of recycled materials.

- Total cost was $\$ 60-70$ of the plant material.

- $\quad$ Assembling time was very short only about thirty minutes (!).

- $\quad$ About $1 \mathrm{~m} 3$ of biogas produces by 2-3 kg (dry matter) kitchen and food waste feedstock.

- Whereas the same quantity of gas to produce needed $28 \mathrm{~kg}$ of cattle dung feedstock.

- The capacity $1.0 \mathrm{~m}^{3}$ gas to hold.

- Enough biogas to cook for 1.5 hours (in total) per day is able to provide.

- Best quality organic fertilizer produces.

- The empty biogas plant around $15 \mathrm{~kg}$ weighs. 


\section{- Easily can be transported.}

So, cooking with biogas plant can reduce organic waste at household's level. The roof top biogas plant can save money by reducing collection and disposal cost of organic waste and cost saving from buying gas cylinder for cooking and can solve the existing environmental problems and energy crises of Dhaka city.

\section{Proposed solution of current organic waste addressing major problems: waste concern approach}

Brief introduction: In 1995, a national research organization "Waste Concern" was established in Bangladesh. The local NGO initiated a small-scale, community-based organic waste recycling project for composting the municipal solid waste. Waste Concern's had three aims initiative: i) Capture value from the organic portion of Dhaka's solid waste, ii) Create job opportunities for the urban poor and iii) Create business opportunities for local entrepreneurs. In 2005, comprising of a number of special purpose companies, Waste Concern Group was formed as a Social Business Enterprise (SBE). The idea of converting waste into resource is the main objective to promote.

Waste concern approach: proposed solution of organic waste management: Waste Concern is a Social Business Enterprise (SBE) set up with the objective to contribute to waste recycling, environmental improvement, sustainable development renewable energy and employment generation for the urban poor.

Addressing two major problems Environmental and health problems in urban areas due to unmanaged waste $(40 \%$ of the waste remains uncollected) and Organic Matter depletion in the soil of rural areas ( $83 \%$ of the soil has less than $3.5 \%$ organic matter), proposed solution Waste Concern's-WWR solution; converting organic waste into compost using Decentralized Network of Compost Plants, use of compost in agriculture and use of carbon credit using Clean Development Mechanism (CDM) project.

Clean development mechanism ( $\mathrm{cdm}$ ) of composting and carbon trading: The opening ceremony of "The World's First Carbon Trading Based Composting Project from organic waste of Dhaka city" was on November 25, 2009. The project is recycling organic vegetable waste converted into compost instead of disposing in landfill (Figure 8). The composting plant stated from 100 tons/day capacity and within 2 years reached 700 tons/ day capacity.

As a critical gap financing measure, Clean Development Mechanism $(\mathrm{CDM})$ can act to supplement early deficits and get projects off the ground until more steady revenue streams arrive. For these projects was estimated to be around 7 years particularly given that the payback period. As of August 31, the price of emission reductions credits (CERs) was 6 US\$/ton (Waste concern, 2003). In the following ways CERs can benefit projects: recover up to $50 \%$ of the project's capital cost, depending on the type of project; and a minimum duration of 10 years utilize earning potential for CERs and maximum of 21 years.

In developing nations of the Asia-Pacific, there is a clear linkage between municipal waste management and climate change. In traditional landfills, organic wastes normally degrade under partly anaerobic conditions and generate methane emissions. Methane is a major contributor to climate change and more potent Greenhouse gas (GHG) than carbon dioxide $\left(\mathrm{CO}_{2}\right)$.

Organic wastes composting are examined as one of the possible way of minimizing this GHG (Figure 9). The "reduce, reuse, recycle" (3R) approach being adopted as part of sustainable development strategies

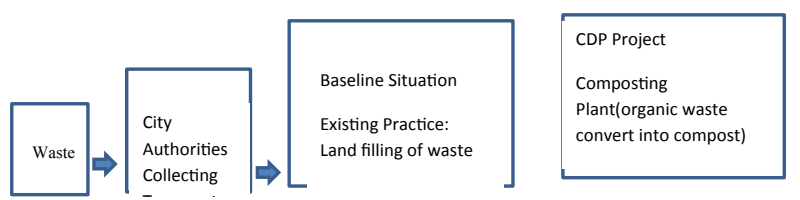

Figure 8: Baseline situation and CDM project.

is consistent with compost from organic waste. It is further evidence of how the climate change and sustainable development can be integrated. Carbon trading (CER/VER) project based between industrialized and developing countries. The CDM project reducing GHG emissions in Dhaka and the emission reductions credits (CERs) is owned by the CDM donor industrialized country(for instance, Dutch company WWR and banks, FMO and Triodos). At the Matuail Waste Disposal site of Dhaka City Corporation, Methane gas emission is being measured by the expert of the Royal Haskoning of the Netherlands and Waste Concern by land fill gas analyser.

\section{Milestones of the CDM project of composting of waste concern:}

- Managing Waste from the DCC area $=700$ tons/day by 2010;

- $\quad$ Production of Compost $=50,000$ tons/year;

- Reduction of Green House Gas = 89,000 tons of $\mathrm{CO}_{2} \mathrm{e} /$ year;

- Job Creation for the Urban Poor $=800$ nos;

- Project Cost $=12$ million Euro.

Waste to composting mechanism in Dhaka city: An innovative "waste to composting" mechanism hosts Dhaka City that has reduced solid waste at source as well as created a market mechanism for sustainable business. With support from the United Nations Development Programme (UNDP), the project is being organized by Waste Concern. In the waste management program, communities are directly involved in this project. By paying fees each household contributes to the collection mechanism. The collected waste is separated, recycled and then sent to a composting plant. Organic waste converts to fertilizer in the composting plant and for local suitability enriches it chemically. The enriched fertilizer is bought by local fertilizer companies and sold on a larger scale. The processes have been sustainable and for its operation except for NGO support and use of land no subsidies have been given by local fertilizer companies.

Strategy adopted for composting: In the urban areas of Bangladesh, the waste management model was developed through experimentation of exploring technical as well as commercial feasibility of labor-intensive decentralized compost production. Two composting techniques Chinese Covered Pile System and Indonesian Windrow Technique were tested in the experimentation project. Due to the problem of odour experiments showed that the Chinese Covered Pile System was not appropriate for the community based projects. The Indonesian Windrow Technique was found to be more appropriate for Bangladesh. In Bangladesh, an attempt was made to make the technique adoptable to the socioeconomic and climate conditions of urban areas. Thus an innovative technique of producing compost gave birth to 'Waste Concern' ultimately. To explore the technical and commercial feasibility is the primary goal of labour-intensive aerobic composting. The technique is based on waste reduction and separation of compostable, recyclables, and other wastes. From the neighbouring community, vegetable markets and local hotels, source-separated organic wastes are collected [15-18]. 


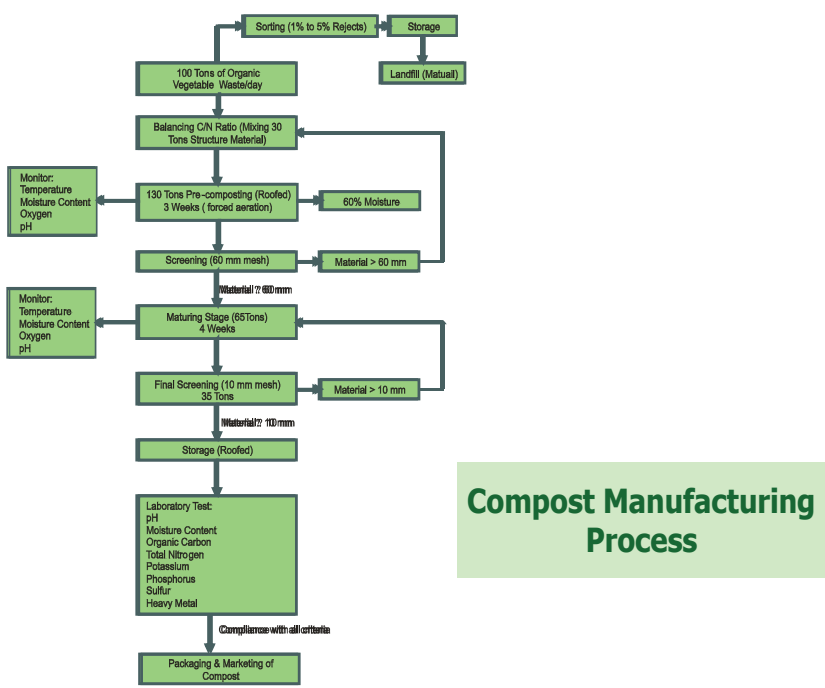

Figure 9: Compost manufacturing process.

Compost manufacturing process: Regardless of scale of operation, the composting process starts with collection of solid waste by the waste collectors from the households in the community. To carry the waste to the compost plant covered rickshaw vans were used. To separate the organic matters from the non-organic waste was the next step by waste collectors who also piled the separated waste under a covered shed for efficient decomposition. Special measures are taken to reduce the odour at a minimum level. For decomposition, the composting process requires 40 days and 10 to 15 days for maturing. The compost is screened for different grades after maturing and packed for marketing through the private partner using their countrywide fertilizer distribution network. The overall composting manufacturing process is shown in Figure 9.

Waste management through public-private-communitypartnerships of waste concern: With active participation of the people, this practice is an example for waste handling in an eco-friendly and cost-effective way. Waste Concern through a network of decentralized composting plants envisioned a strategy for zone-wise waste management, and the establishment of successful partnerships not just with government but with the private sector. Waste Concern has succeeded in developing a community-based solid waste management model for Dhaka through facilitating innovative arrangements between different levels of government, the private sector and local communities, which many other cities in Bangladesh and in other developing countries are seeking to follow. This model has improved not only the urban environment but also the quality of lives of poor people living in slums with its emphasis on recycling and resource recovery [19-22].

Calculation of savings: waste is a resource: Waste Concern was formed to attain a common vision to contribute to waste recycling, environmental improvement, and renewable energy, employment generation for the urban poor and sustainable development. The model has been proved commercially viable and sustainable and clearly demonstrated large scale economic, social and environmental benefits for the urban dwellers by attaining these objectives. Figure 10 shows waste is a resource.

Process quality control: The Quality Control of processing is done by Forced Aeration and Leachate Collection System to reduce Methane and avoid anaerobic condition. Time to time oxygen control of the composting is being done and safe working condition of the workers provide by waste concern for composting.

Application of the compost in fields: Field trial of compost produced by WWR Bio on Rice results reduces use of chemical fertilizer by $25 \%-50 \%$ and increase yield up to30\% (Figure 11 ).

Pro-poor elements of the project: Due to increasing unemployment and lack of job opportunities, a large group of urban poor of Dhaka City are gradually getting involved in the recovery process of inorganic recyclable materials from waste with economic value for their survival (Figure 11). It is estimated by a study that $55 \%$ population lives below the poverty line of Dhaka. Although this poor labour force plays an important role in reducing waste in Dhaka city ( $15 \%$ of the total solid waste generated) to be managed by DCC their contribution remains largely unrecognized. Ironically a huge portion of organic matter (almost $80 \%$ of the waste) collected by these poor people with the potentials of converting it into economic resource (compost/organic fertilizer) remains totally unutilized.

The initiative has multiple economic, social and environmental implications for Bangladesh. For the urban poor it contributes to creating employment opportunities in its activities like waste collection from the households, and other activities in the composting plants. In the composting process involving women contributes to their empowerment in the society, and improve quality of life in the households. Other benefits generated include saving of landfill area, reduction in top soil fertility degradation, increased agricultural yield, reduction in greenhouse gas emissions and reduction in harmful effects of chemical fertilizers on local fish and wild life through this initiative.

The major impacts of the project: The major impacts of the project are as follows:

- In the area, environmental pollution such as air, water and soil pollution has significantly reduced.

- The existing dust bins do not use by the project members (H.H) for disposing their daily wastes anymore which help reduce air pollution and scatter wastes in the neighbourhood.

- In the houses, as the wastes (Organic and Inorganic) are separated and disposed in different containers it became easier for the project authority to sell the inorganic materials to the retailers and recycle company.

- $\quad$ The project monitors secondary dumping sites which help
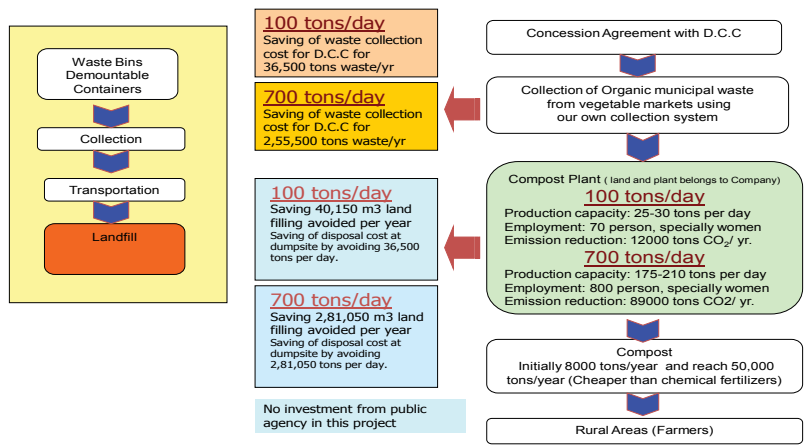

Figure 10: Calculation of savings: waste as a resource; source: waste concern. 


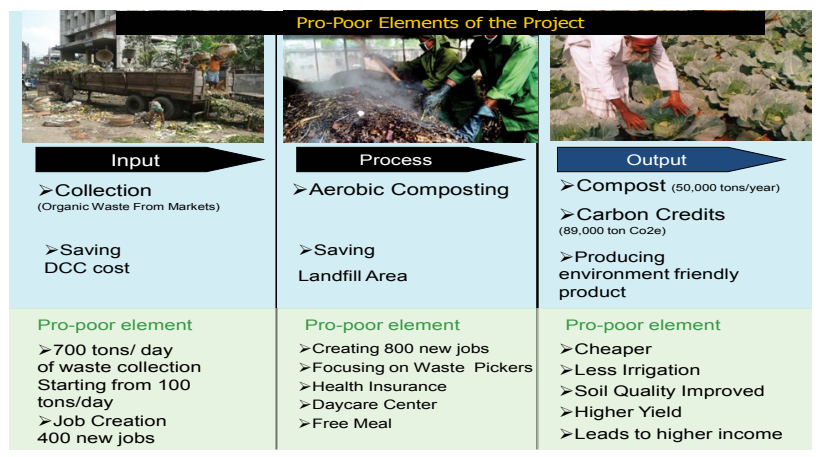

Figure 11: Pro-poor elements of the project: source: waste concern.

reduce scattering waste outside the bins and adjacent road.

- The project has helped to generate positive behavioural changes of the community of Dhaka city.

Major obstacles of the project: Due to lack of public awareness and motivation the project authority could not expand the project satisfactorily. No massive awareness-building programme has been launched in the area by DCC.

\section{Key Forward}

- This project required for 53 (fifty three) permissions/ clearance before implementation. To simplify this lengthy process/ barrier is needed.

- $\quad$ About CDM projects, we need to enhance the capacity of the staff and officials of public and private sector.

- We need to recognize these kind of projects which has both the adaptation and mitigation benefits.

- For CDM projects, one stop approval process should be introduced (CDM/BOI/ Bangladesh Bank/Line Ministry) to encourage $\mathrm{CDM}$ investment.

- There are many investors keen to invest which has both mitigation and adaptation benefits in the projects

\section{Conclusion}

For DCC, strategies for efficient solid waste management are to carry out institutional strengthening, capacity building and gradual private sector participation in solid waste management. In particular, promotion of community-based programs and local initiatives with NGO support are important and the formulation of laws and regulations. Examples from Surabaya could be useful to DCC which is based on community managed collection. Such experiences in managing solid waste issues would be of good reference to DCC. Similarly, other cities can learn valuable insights from Dhaka's successful and replicable composting program. The model of decentralized community-based composting by Waste Concern has demonstrated enough evidence that an effective partnership arrangement can be developed between the public sector, the community, and the private sector.
In a multistoried building of DCC, rooftop tube-type biogas plant can help to improve the waste management, produce biogas and organic fertilizer which could be used in rooftop gardening. So, cooking with biogas plant can reduce organic waste at household's level. The roof top biogas plant can save money by reducing collection and disposal cost of organic waste and cost saving from buying gas cylinder for cooking and can solve the existing environmental problems and energy crises of Dhaka city.

\section{References}

1. Krieibich V (2012) Mega Cities: Mega Challenges, International Seminar paper at BRAC.

2. Matter A, Dietschi M, Zurbrügg C (2013) Improving the Informal Recycling Sector Through Segregation of Waste in the Household -The Case of Dhaka Bangladesh. Habitat Int 38: 150-156.

3. Bangladesh W (2012) Waste News. WasteNet Bangladesh.

4. Begum A (1999) Destination Dhaka, Urban Migration: Expectations and Reality. University Press Limited (UPL).

5. Begum A (2005) Urban Poverty Study.

6. http://www.wasteconcern.org/Publication/CDM_Brochure.pdf

7. No Authors Listed (2005) Dhaka City State of Environment Report.

8. Islam AZMS (2008) Solid Waste Management in Dhaka City.

9. DCC (1999) Solid Waste Management in Dhaka City Corporation. Dhaka City Corporation, Dhaka.

10. Enayetullah I, Sinha AHMM (2003) Decentralized Composting through PublicPrivate Community Partnerships: Experience of Waste Concern.

11. Imtiaz N, Alam SM (2002) Health Care Waste of Dhaka City: A SocioEnvironmental Assessment. In: Ahmed AF, Tanveer SA, Badruzzaman ABM (eds.). Bangladesh Environment, Bangladesh Poribesh Andolon, Dhaka.

12. JICA (2004) Necessity for Institutional Strengthening. Paper presented by Dr. Nagayma, team leader, JICA Study Team on Solid Waste Management of Dhaka City.

13. https://tradingeconomics.com/bangladesh/population-in-largest-city-wb-data html

14. Iftekhar, Maqsood (2003) Decentralized Composting, Waste Concern, Dhaka, Bangladesh Waste Concern, 2008, Clean Development Mechanism and its Opportunities in Bangladesh, Waste Concern, Dhaka, Bangladesh.

15. http://www.wasteconcern.org/Publication/ESCAP_pro-poor_SWM.pdf

16. Reazuddin, Mohammad (2011) Globally the First Organic Waste Composting Project Using Carbon Trading Project: Experience of Waste Concern.

17. http://open_jicareport.jica.go.jp/pdf/11785235.pdf

18. http://ccap.org/resource/success-stories-in-the-waste-sector/

19. Tanzina Azad (2004) Challenge for a Clean City (Dhaka) LAC Project, IIIEE Department, Lund University The Daily Star.

20. http://www.thedailystar.net/news-detail-262171

21. Waste Concern (2006) Decentralised Composting for Cities of Low and Middle Income Countries, A users' Manual, Waste Concern, Dhaka, Bangladesh, and Duebendorf, Switzerland.

22. https://energypedia.info/wiki/TyreTube_Biogas_Plant 